\title{
The Coffin-Lowry Syndrome-Associated Protein RSK2 Regulates Neurite Outgrowth through Phosphorylation of Phospholipase D1 (PLD1) and Synthesis of Phosphatidic Acid
}

\author{
Mohamed-Raafet Ammar, ${ }^{1}$ Yann Humeau, ${ }^{2}$ André Hanauer, ${ }^{3}$ Bernard Nieswandt, ${ }^{4}$ Marie-France Bader, ${ }^{1}$ \\ and Nicolas Vitale ${ }^{1}$ \\ ${ }^{1}$ Institut des Neurosciences Cellulaires et Intégratives, Centre National de la Recherche Scientifique UPR-3212, Université de Strasbourg, 67084 Strasbourg, \\ France, ${ }^{2}$ Institut Interdisciplinaire de Neuroscience, Centre National de la Recherche Scientifique UMR-5297, Université de Bordeaux, 33077 Bordeaux \\ Cedex, France, ${ }^{3}$ Institut de Génétique et de Biologie Moléculaire et Cellulaire, Centre National de la Recherche Scientifique, Institut National de la Santé et \\ de la Recherche Médicale, UMR-7104/U964 Université de Strasbourg, 67404 Illkirch Cedex, France, and ${ }^{4}$ University Hospital and Rudolf Virchow Center, \\ Deutsche Forschungsgemeinschaft Research Center for Experimental Biomedicine, 97080 Würzburg, Germany
}

More than 80 human X-linked genes have been associated with mental retardation and deficits in learning and memory. However, most of the identified mutations induce limited morphological alterations in brain organization and the molecular bases underlying neuronal clinical features remain elusive. We show here that neurons cultured from mice lacking ribosomal S6 kinase 2 (Rsk2), a model for the Coffin-Lowry syndrome (CLS), exhibit a significant delay in growth in a similar way to that shown by neurons cultured from phospholipase D1 (Pld1) knock-out mice. We found that gene silencing of Pld1 or Rsk2 as well as acute pharmacological inhibition of PLD1 or RSK2 in PC12 cells strongly impaired neuronal growth factor (NGF)-induced neurite outgrowth. Expression of a phosphomimetic PLD1 mutant rescued the inhibition of neurite outgrowth in PC12 cells silenced for RSK2, revealing that PLD1 is a major target for RSK2 in neurite formation. NGF-triggered RSK2-dependent phosphorylation of PLD1 led to its activation and the synthesis of phosphatidic acid at sites of neurite growth. Additionally, total internal reflection fluorescence microscopy experiments revealed that RSK2 and PLD1 positively control fusion of tetanus neurotoxin insensitive vesicle-associated membrane protein (TiVAMP)/VAMP-7 vesicles at sites of neurite outgrowth. We propose that the loss of function mutations in RSK2 that leads to CLS and neuronal deficits are related to defects in neuronal growth due to impaired RSK2-dependent PLD1 activity resulting in a reduced vesicle fusion rate and membrane supply.

\section{Introduction}

Coffin-Lowry syndrome (CLS) is a rare syndromic form of mental retardation that shows X-linked inheritance (Hanauer and Young, 2002). Key features of CLS are growth and psychomotor retardation, characteristic facial and digital abnormalities, and progressive skeletal alterations (Manouvrier-Hanu et al., 1999). CLS is caused by heterogeneous loss-of-function mutations in the RSK2 (90 kDa ribosomal S6 kinase) gene (RPS6KA3), which maps to Xp22.2 (Trivier et al., 1996). RSK2 is a serine-threonine protein kinase of $740 \mathrm{aa}(90 \mathrm{kDa})$ that belongs to a family of four

\footnotetext{
Received May 29, 2013; revised Oct. 4, 2013; accepted 0ct. 31, 2013.

Author contributions: Y.H., M.-F.B., and N.V. designed research; M.-R.A. and N.V. performed research; Y.H., A.H., and B.N. contributed unpublished reagents/analytic tools; M.-R.A. and N.V. analyzed data; M.-F.B. and N.V. wrote the paper.

This work was supported by Agence Nationale de la Recherche Grant ANR-09-BLAN-0326-01 (to N.V.), Fondation Jérôme Lejeune (to A.H.), and the Deutsche Forschungsgemeinschaft Grant Ni556/8-1 (to B.N.). We thank T. Thahouly and V. Calco for technical assistance, Drs. S. Chasserot-Golaz, S. Gasman, N. Grant, and S. Ory for critical reading of the manuscript, and the microscopy facilities of Plateforme Imagerie In Vitro. pHluorin-VAMP-7 was provided by Dr. T. Galli (Institut Jacques Monod, Paris).

Correspondence should be addressed to Nicolas Vitale at the above address. E-mail: vitalen@inci-cnrs.unistra.fr. DOI:10.1523/JNEUROSCI.2283-13.2013

Copyright $\odot 2013$ the authors $\quad 0270-6474 / 13 / 3319470-10 \$ 15.00 / 0$
}

members, RSK1-RSK4, which share a highly conserved structure and are widely expressed in mammals and cell types. RSK2 was first described to act at the distal end of the ras-mitogen-activated protein kinase signaling pathway (Frödin and Gammeltoft, 1999). Different substrates of RSK2 subsequently identified include such transcription factors as ATF4, cFOS, and CREB (Pereira et al., 2010). Activation of RSK2 is, therefore, thought to influence gene expression and to be involved in cell proliferation and survival.

In human and mouse, the highest levels of RSK2 expression are observed in regions with high synaptic activity, including the neocortex, the hippocampus, and Purkinje cells, which are essential components in cognitive function and learning, suggesting that RSK2 might function in these processes (Zeniou et al., 2002). Indeed, deletion of RSK2 orthologue S6KII in Drosophila leads to short-term memory defects in a classical olfactory learning paradigm. The Rsk2-null mouse created as a model for CLS develops a progressive osteopenia due to impaired osteoblast function (Yang et al., 2004). Although no major brain abnormalities are evident at the anatomical and histological levels in Rsk2-knockout (Rsk2-KO) mice, behavioral studies reveal profound retarda- 


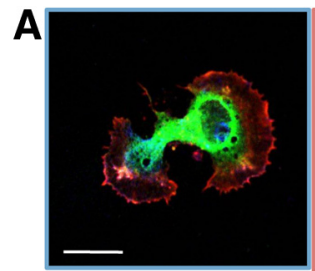

B

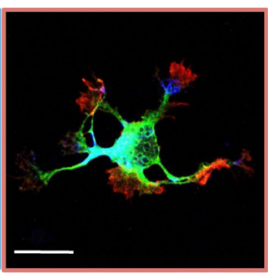

Stage 2

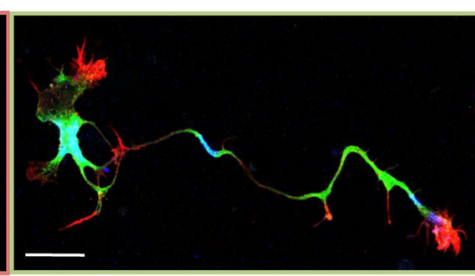

Stage 3

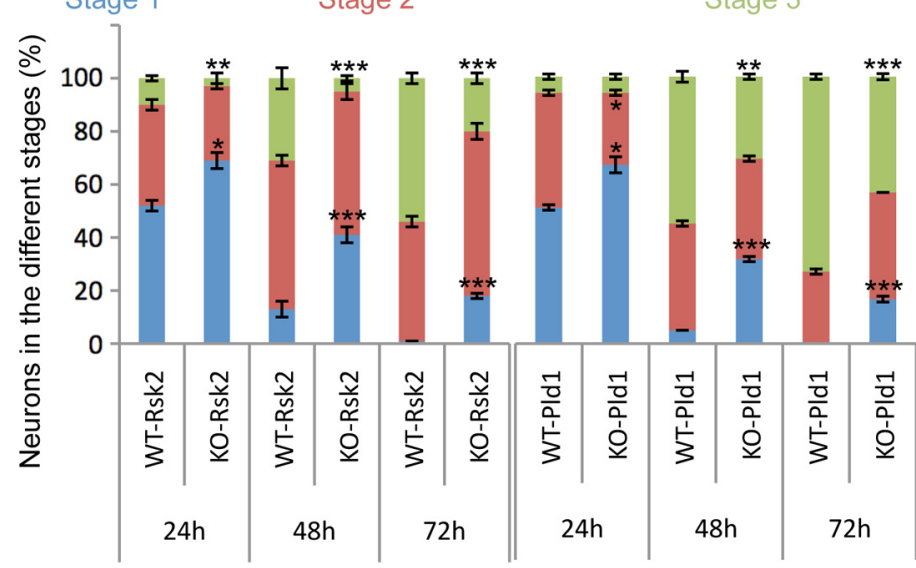

Figure 1. Involvement of RSK2 and PLD1 in neurite outgrowth. $A$, Cortical neurons from $R s k 2^{-1-}$, PId $1^{-1-}$, or WT mice were stained for F-actin (red), $\beta$ tubulin (green), and the DNA dye DRAQ5 (blue) at various stages of development. Scale bars, $10 \mu \mathrm{m}$. B, Percentage of cells at Stage 1, 2, or 3 counted after 24,48 , or $72 \mathrm{~h}$ in culture. At least 150 cells were counted for each condition. Similar observations were obtained with $\geq 3$ different cell cultures. Statistical analyses were performed between the corresponding $\mathrm{KO}$ and WT pairs for each day of culture tested. Asterisks are placed above the corresponding error bars.

Plasmids and siRNA sequences have been described previously (Corrotte et al., 2006; ZeniouMeyer et al., 2007, 2008). pHluorin-VAMP-7 was provided by Dr. T. Galli (Institut Jacques Monod, Paris).

Animals and tissue dissection. Pld $1^{-1-}$ and Rsk $2^{-1-}$ mice were described previously (Yang et al., 2004; Elvers et al., 2010). All experiments were performed in accordance with the European Community's Council Directive of November 24, 1986 (86/609/EEC). Every effort was made to minimize the number of animals used and their suffering.

Cell culture and NGF treatment. Cortical neurons were cultured from embryonic day 15 mice of either sex in Neurobasal medium (Invitrogen) supplemented with $2 \% \mathrm{~B}-27,1 \%$ GlutaMAX, and 1\% Pen/Strep. Low-density cultures were plated on poly-L-lysine (SigmaAldrich)-coated glass coverslips at 25,000 neurons $/ \mathrm{cm}^{2}$. For the analysis of early neurite outgrowth (DIV1-DIV3), random images were taken of the cultures using a $63 \times$ lens on a Leica SP5II confocal microscope. Cultured $80 \%$ confluent PC12 cells were transfected by Lipofectamin 2000 (Lam et al., 2008). When indicated, drugs were applied $30 \mathrm{~min}$ before NGF treatment. NGF was applied to cells $48-72 \mathrm{~h}$ after transfection at $50 \mathrm{ng} / \mathrm{ml}$ and added freshly every $24 \mathrm{~h}$. Cells developing neurites were counted and the neurite length measured using ImageJ software with Simple neurite tracer plug-in.

tion in spatial learning and a deficit in long-term spatial memory (Poirier et al., 2007). On the other hand, a number of subtle neuroanatomical abnormalities have been found in CLS individuals (Hunter, 2002; Stephenson et al., 2005). For example, a morphometric MRI-based study of CLS brain morphology has revealed a reduced total brain volume that appeared to be correlated with the severity of CLS outcome (Kesler et al., 2007). Altogether, these observations favor a role for RSK2 in the development and plasticity of neuronal circuits, but the molecular basis for this function remains elusive.

In agreement with a direct role of RSK2 in neurotransmission, we recently described RSK2 as a critical upstream signaling element in the activation pathway of phospholipase D1 (PLD1), which produces fusogenic lipids required for calcium-regulated exocytosis (Zeniou-Meyer et al., 2008, 2009). Considering that both PLD1 and PLD2 have been implicated in the regulation of neurite growth in neural cell lines and neural stem cells (Kanaho et al., 2009), we decided to investigate whether mutations or loss of expression of RSK2 interfere with the growth and development of neurons by modulating PLD activity. Using cultures of cortical neurons from transgenic mice models and PC12 cells, we demonstrate that RSK2 is an essential modulator of PLD1 activity and is required for neurite outgrowth.

\section{Materials and Methods}

Materials. Antibodies anti- $\beta$-tubulin (Cell Signaling Technology), antiRSK2 (Santa Cruz Biotechnology), anti-PLD1, anti-SNAP25, anti-ERK, anti-phospho-ERK, anti-phospho-RSK (New England BioLabs), antimicrotubule-associated protein 2 (MAP2) (Sigma-Aldrich), and antiphospho-PLD1 (Thr-147; Cell Signaling Technology) were used. The RSK inhibitor BI-D1870 was obtained from Enzo Life Sciences, the PLD1 inhibitor CAY-10593 (CAY-93) from Interchim, DRAQ5 from Biostatus, and neuronal growth factor (NGF), phaloïdin-tetramethylrhodamine B, and 5-fluoro-2-indolyl des-chlorohalopemide (FIPI) from (Sigma-Aldrich).
Determination of PLD activity. PC12 cells were incubated with medium or medium containing the different drugs for $30 \mathrm{~min}$ and then incubated for $30 \mathrm{~min}$ with NGF $(50 \mathrm{ng} / \mathrm{ml})$. PLD activity was measured as described previously (Lopez et al., 2012). The PLD activity of the cell not treated with NGF was subtracted. Data are given as the mean of six determinations performed on $\geq 3$ different cell preparations \pm SEM.

Western blot and immunoprecipitation. After treatment, cells were lyzed and proteins were resolved by SDS $4-12 \%$ PAGE. Proteins were transferred to nitrocellulose membranes as described previously (de Barry et al., 2006). Detection was performed by chemiluminescence by using the Super Signal West Dura Extended Duration Substrate (Pierce). For immunoprecipitation, protein extracts were prepared in lysis buffer (50 mm HEPES, 3 mm EGTA, $3 \mathrm{~mm} \mathrm{CaCl}_{2}, 3 \mathrm{~mm} \mathrm{MgCl}$, $80 \mathrm{~mm} \mathrm{KCl}, 0.1 \%$ Triton X-100, $0.1 \%$ sodium deoxycholate, $1 \mathrm{~mm}$ sodium orthovanadate, $40 \mathrm{~mm} \mathrm{NaF}$, and protease inhibitor mixture; Sigma-Aldrich). Five hundred micrograms of total protein were used. Quantification of Western blots was performed as described earlier (Béglé et al., 2009).

Immunocytochemistry. Neurons and PC12 cells were fixed and further processed for immunofluorescence as described previously (Vitale et al., 1998). Stained cells were visualized with a Leica SP5II confocal microscope. Colocalization level of Spo20p and SNAP25 was estimated as described previously (Zeniou-Meyer et al., 2007). Quantification of RSK2 and PLD1 colocalization was performed for each condition on $30 \mathrm{se}-$ lected regions of interest on the membrane ruffles from 15 cells using ImageJ.

Live cell imaging and total internal reflection fluorescence microscopy. PC12 cells were transfected with PLD1-green fluorescent protein (PLD1GFP) or VAMP-7-pHluorin and incubated with NGF overnight. The next day, optical recordings were performed using a Axiovert 200 with Moane TIRF-2 total internal reflection fluorescence (TIRF) microscope (Zeiss) equipped with a $100 \times$ objective, a 1.45 numerical aperture, and an ImageM camera (Hamamatsu). Temperature was maintained at $37^{\circ} \mathrm{C}$ during recording. Under the conditions of observation used, one pixel corresponded to $160 \mathrm{~nm}$. Stream acquisitions were performed at $1.44 \mathrm{~Hz}$ for $3 \mathrm{~min}$ with an exposure time of $280 \mathrm{~ms}$. Selective excitation was obtained using argon laser lines at $488 \mathrm{~nm}$. Optical bandpass filters (500- 
A

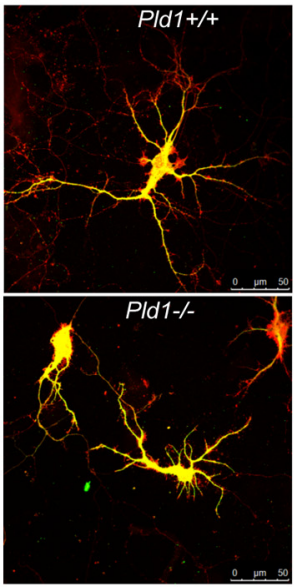

D

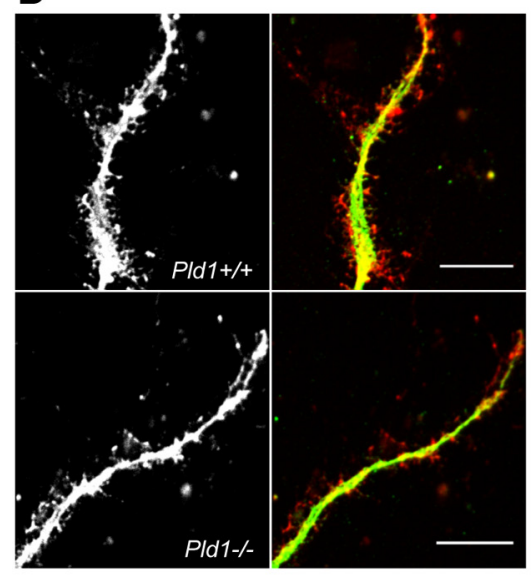

B

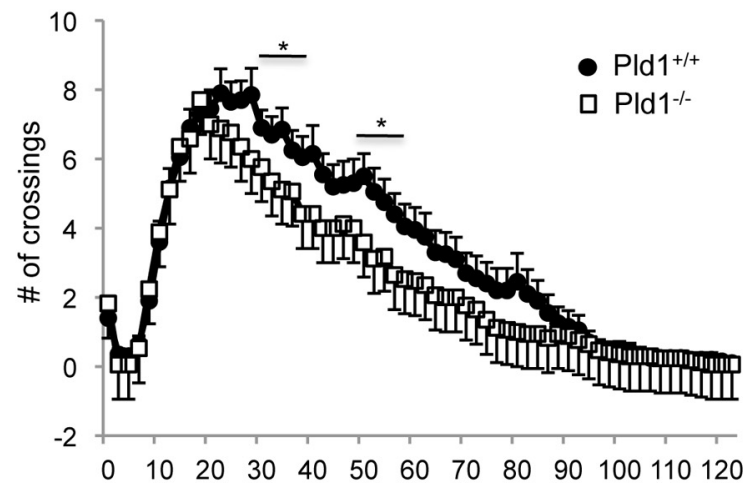

Distance from soma along dendrite $(\mu \mathrm{m})$
C

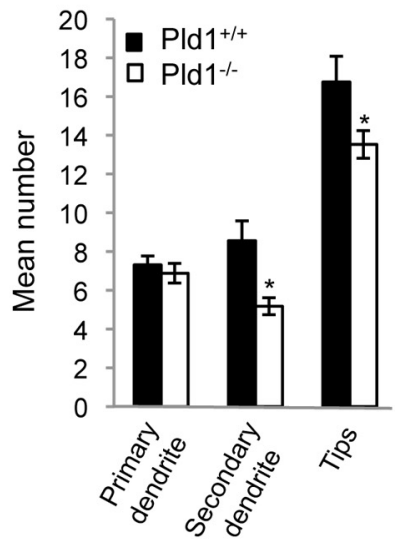

E

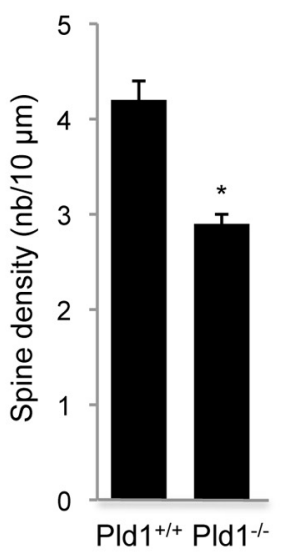

F

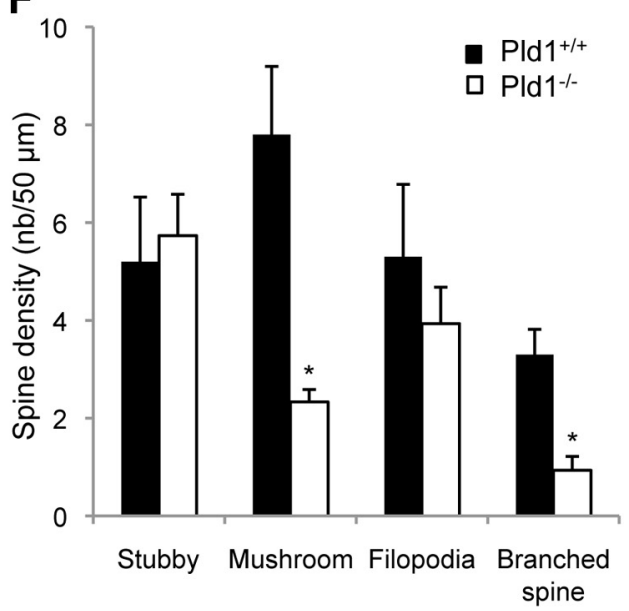

Figure 2. PLD1 K0 affects neuronal development. $A$, Typical neurons from $P I d 1^{+/+}$and $P I d 1^{-/-}$mice at 10 DIV. Scale bar, $50 \mu \mathrm{m}$. B, Sholl analysis revealed a significantly reduced number of crossings in Pld1 ${ }^{-1-}$ ( $n>25$ cells in each condition). C, Quantification of primary and secondary dendrites and neurite tips ( $n>20$ cells in each condition). D, Typical actin (red) and MAP2 (green) staining neurons from PId $1^{+/+}$and PId $1^{-/-}$mice at $10 \mathrm{DIV}$. Scale bar, $10 \mu \mathrm{m}$. E, Quantification of PLD1 K0 effect on the spine linear density. F, Quantification of PId $1 \mathrm{KO}$ effect on spine morphology by counting the number of stubby, mushroom, filopodia, and branched spine. Similar observations were obtained with $\geq 3$ different cell cultures ( $n>25$ cells in each condition).

$540 \mathrm{~nm}$ ) were used for the emission. Fusion events of VAMP-7pHluorine vesicles were manually counted by using ImageJ software. The interval between successive fusion events was calculated for each cell imaged and represented in frequency. Drugs were applied $30 \mathrm{~min}$ before recording.

Statistics. Statistical analysis was performed with $\mathrm{R}$ software using parametric ( $t$ test; see Figs. $1-7)$ and nonparametric (Wilcox test; see Fig. $9)$ tests compared with the corresponding control condition $\left({ }^{*} p<0.05\right.$; $\left.{ }^{* *} p<0.01 ;{ }^{* * *} p<0.001\right)$.

\section{Results}

RSK2 and PLD1 are involved in neurite outgrowth

Axon and dendrite outgrowth are critical events in the establishment of neuronal networks during brain development. This complex process is not fully understood, but the forming neurons appear to go through at least three morphologically distinct steps (Craig and Banker, 1994): Stage 1, formation of lamelliopodia; Stage 2, sprouting of multiple neurites similar to each other in structure and composition; and Stage 3, differentiation of neurites into either axons or dendrites (Fig. 1A). The establishment of synapses and networks are the last steps in the formation of mature neurons. We cultured cortical neurons from Rsk2-null mouse and found a dramatic delay in this process compared with neurons cultured from WT littermates (Fig. 1B). At $24 \mathrm{~h}$ of culture, a significant proportion of neurons from $\mathrm{Rsk} 2^{-/-}$mice were still in the first stage of development. At $72 \mathrm{~h}$, when most neurons of WT mice had progressed through the second and third phases of development, $20 \%$ of $R s k 2^{-/-}$neurons were still at Stage 1 (Fig. 1B). Conversely, the proportion of neurons reaching Stage 3 in the Rsk2-null mice was significantly reduced (Fig. $1 B)$. Since PLD1, but not PLD2, contains a RSK2 phosphorylation site at Thr147, we also examined cortical neurons from Pld1null mouse. As illustrated in Figure $1 B, P l d 1^{-1-}$ neurons displayed a delay in outgrowth that was very similar to that of $R s k 2^{-1-}$ neurons. Additionally, the average axonal length in control neurons $(143 \pm 7 \mu \mathrm{m})$ was reduced by $32 \%$ in $R s k 2^{-/-}$ neurons and by $29 \%$ in $P l d 1^{-1-}$ neurons.

To further test the hypothesis that PLD1 plays a role in neurite outgrowth and may thereby be involved in neuronal development, we investigated the effect of PLD1 knockout on subsequent neuronal development hallmarks using the $P l d 1^{-/-}$mice. Dendritic morphogenesis is an important step for the establishment of neural circuitry. The number of primary dendrites arising from the cell body, higher-order dendrites emerging from primary dendrites, and dendritic branching patterns appear to be critical for neuronal function (Jan and Jan, 2010). Pld1 KO affected dendritic branching at 10 days in vitro (DIV), as observed by Sholl analysis (Fig. $2 A, B$ ), a standard assay for measuring dendritic complexity (Jaworski et al., 2005). Although we found 

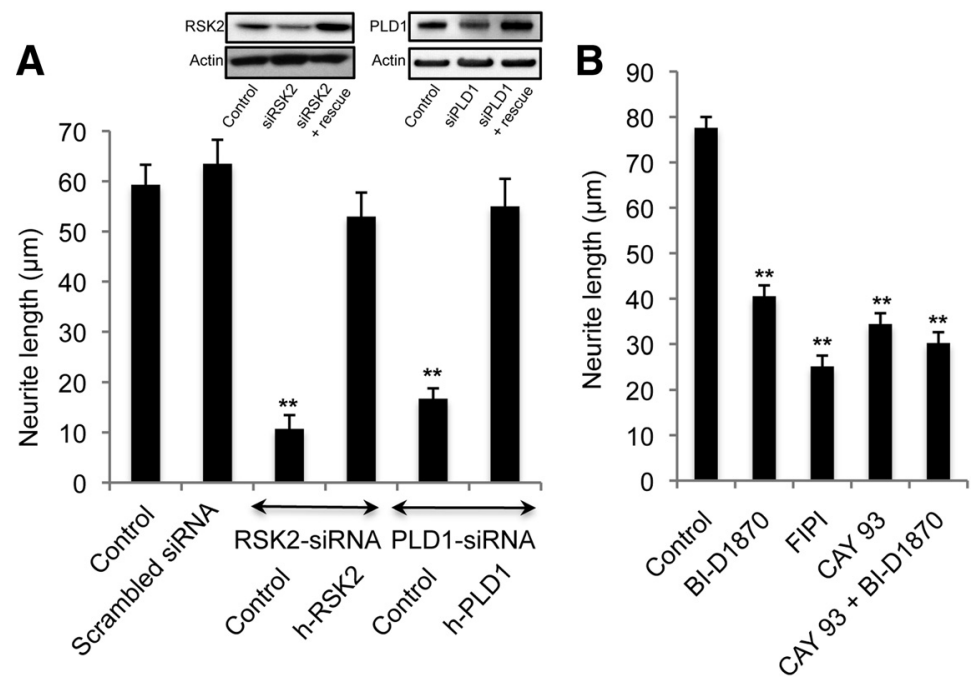

Figure 3. RSK2 and PLD1 play a role in NGF-induced neurite outgrowth in PC12 cells. $A$, Insets depict the expression level of RSK2 and PLD1 $3 \mathrm{~d}$ after PC12 cells were transfected with the indicated siRNA constructs and/or rescue plasmids. Actin staining serves as loading control. Neurite length from PC12 cells silenced for RSK2 or PLD1 expression after $3 \mathrm{~d}$ of NGF treatment. Coexpression of siRNA-resistant construct (human-RSK2 or human-PLD1) rescued the phenotype. $B$, Neurite length from PC12 cells exposed for 30 min to the RSK2 inhibitor BI-D1870 and/or to the PLD1 inhibitor (FIPI or CAY-93) before NGF addition for $3 \mathrm{~d}$. Similar observations were obtained with $\geq 3$ different cell cultures ( $n>25$ cells in each condition).
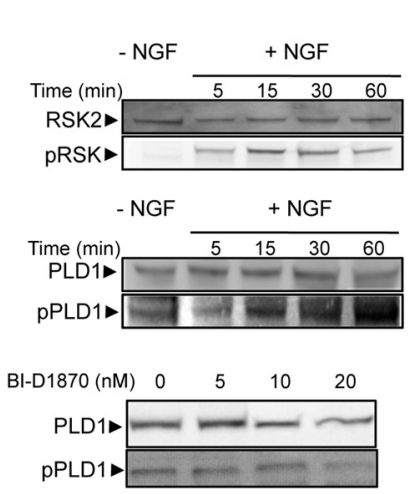

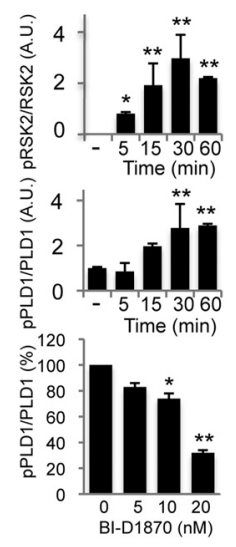

Figure 4. NFG stimulation triggers RSK2 and PLD1 phosphorylation in PC12 cells. Cells were stimulated with NGF ( $50 \mathrm{ng} / \mathrm{ml}$ ) for $5-60 \mathrm{~min}$ and the levels of phosphoproteins and total RSK2 and PLD1 proteins were examined by Western blotting and quantified. A 30 min pretreatment with the RSK2 inhibitor BI-D1870 inhibited NGF-induced PLD1 phosphorylation in a dosedependent manner (pPLD1/PLD1 levels were normalized to the control condition in absence of BI-D1870). Quantifications were performed on three independent experiments.

no significant differences in the number of primary branching dendrites, the number of secondary branching dendrites was significantly reduced in neurons cultured from $\mathrm{Pld}^{-1-}$ mice (Fig. $2 C$ ). Because the dendritic tips were at the terminal branches and reflected the complexity of dendrites, we next analyzed whether the number of dendritic tips was altered in neurons lacking PLD1. Consistent with the reduction in secondary dendritic branching, the number of dendritic tips was decreased in neurons from $\mathrm{Pld}^{-1-}$ mice (Fig. $2 \mathrm{C}$ ).

Dendritic spines are key features for neuronal development and synaptic function. For instance, the density and morphology of dendritic spines are directly correlated with their functions. To test the possibility that PLD1 is involved in dendritic spine development, we used actin labeling to outline dendritic spines in cultured cortical neurons (Fig. 2D). In agreement with the possi- bility that PLD1 is involved in neuronal development, we found a significant decrease in total spine density in 10 DIV Pld $1^{-1-}$ neurons (Fig. 2E). In fact, this reduction in spine density specifically affected mushroom and branched spines, which are the forms of mature spines (Fig. $2 F$ ). These observations suggest a reduced level of functional synapses in neurons lacking PLD1. Although early pharmacological approaches have postulated that PLD1/2 could be involved in neurite outgrowth, this is the first report using Pld1-null mouse that validates this idea and supports the concept that this may have a long-term effect on neuronal development.

\section{NGF stimulation triggers RSK2- dependent phosphorylation and activation of PLD1 in PC12 cells} The possible interplay between RSK2 and PLD1 in neurite outgrowth was further investigated using the classical NGFinduced neurite outgrowth assay in pheochromocytoma PC12 cells. Effective silencing of PLD1 and RSK2 was obtained in PC12 cells (Fig. 3A, insets). Based on transfection efficiencies, we calculated that the silencing level for PLD1 and RSK2 was 87 and $93 \%$, respectively, in agreement with our previous observations in PC12 cells (Zeniou-Meyer et al., 2007, 2008). Both reduction of RSK2 or PLD1 expression by siRNA-silencing experiments affected neurite outgrowth in response to NGF stimulation (Fig. $3 A$ ). Rescue experiments performed by coexpressing RSK2 or PLD1 constructs insensitive to siRNA ruled out possible off-target effects of the siRNAs (Fig. 3A). Similar results were obtained using pharmacological inhibitors. NGF-induced neurite outgrowth in PC12 cells was potently inhibited by the RSK inhibitor BI-D1870 (Sapkota et al., 2007) and by the dual PLD1/ PLD2 inhibitor FIPI (Su et al., 2009) and the PLD1 isoformspecific inhibitor CAY-93 (Lewis et al., 2009; Fig. 3B). Note that we did not observe an additive effect of the RSK2 and PLD1 inhibitor, suggesting that the two proteins may control the same pathway during neurite outgrowth.

To dissect the signaling pathway linking NGF stimulation to RSK2 and PLD1, PC12 cells were challenged with NGF for different periods of time and phosphoproteins were detected in cell extracts by Western blotting. NGF stimulation produced progressive and parallel increases in the level of phosphorylated RSK2 and PLD1, reaching a plateau at 15 min (Fig. 4). Interestingly, the RSK inhibitor BI-D1870 was found to block in a dosedependent manner the NGF-induced phosphorylation of PLD1 (Fig. 4), in agreement with the idea that PLD1 might be a target activated by phosphorylated RSK2 upon NGF stimulation.

The intracellular distribution of overexpressed RSK2 and PLD1 is depicted in Figure 5. In resting PC12 cells, RSK2 displayed a nuclear and perinuclear distribution, whereas PLD1 was mostly found in the periphery of the nucleus most likely associated with vesicular structures (Fig. 5A). A 30 min stimulation with NGF induced a change in PC12 cell morphology (ruffles) and caused a partial redistribution of both PLD1 and RSK2 to the cell periphery, where the two proteins appeared to colocalize (Fig. $5 A$, arrowheads). Quantification revealed that at membrane ruffles, $94.2 \pm 1.0 \%$ of RSK2 and PLD1 signals colocalized. This 
recruitment of GFP-PLD1 to the periphery of NGF-treated cells is in line with the ability of PLD1 to cycle from vesicular structures to the plasma membrane (Vitale et al., 2001; Du et al., 2003). Coimmunoprecipitation experiments of endogenous RSK2 and PLD1 confirmed that both proteins were associated in the same complex in NGF-treated cells (Fig. 5B). Additionally, we found that NGF induced a potent increase in PLD activity $(\sim 80 \%)$ that was completely blocked by the broad-spectrum PLD inhibitor FIPI and strongly inhibited by the specific PLD1 inhibitor CAY-93, suggesting that NGF mainly stimulated type 1 PLD activity (Fig. 5C). RSK2 inhibition by BI-D1870 also significantly prevented NGF-induced PLD1 activation (Fig. 5C). These results suggest that NGF stimulation triggers the recruitment of RSK2 and PLD1 to growing neurite endings where activated RSK2 phosphorylates and activates PLD1.

\section{NGF-evoked neurite outgrowth is mediated by RSK2-induced PLD1 phosphorylation on Thr-147}

RSK2 has been shown to activate PLD1 by phosphorylating Thr147 residue (ZeniouMeyer et al., 2008). To reinforce the idea that the phosphorylation of PLD1 by RSK2 is important for neurite outgrowth, we measured neurite length after NGF treatment in PC12 cells expressing RSK2 siRNAs and attempted to rescue growth with WT or mutated PLD1 proteins. In cells with a reduced RSK2 level, neither expression of PLD1 WT nor PLD1(T147A), a phosphorylation-deficient mutant, restored neurite outgrowth (Fig. 6). In contrast, expression of the phosphomimetic PLD1(T147E) mutant restored growth despite the reduced RSK2 level. Note that the dual phosphomometic and kinase dead mutant PLD1(T147E-K898R) was unable to rescue neurite outgrowth from KSK2 knockdown PC12 cells (Fig. 6), suggesting that the lipase activity of PLD1 is required for the rescue effect. These results are consistent with a sequence of events in which NGF leads to RSK2 phosphorylation and activation, which in turn phosphorylates PLD1 on Thr147, stimulating PLD1 activity and promoting neurite outgrowth.

Phosphatidic acid synthesis at sites of neurite outgrowth PLD1 is responsible for the production of phosphatidic acid (PA). Thus we examined PA synthesis in PC12 cells using the PA-binding domain of Spo20p fused to GFP as a PA sensor (Zeniou-Meyer et al., 2007; Kassas et al., 2012). In resting cells, Spo20p-GFP was present in the nucleus, but after a $30 \mathrm{~min}$ application of NGF, a significant fraction was recruited to the plasma membrane, where it colocalized with SNAP25 (Fig. $7 A, B$ ). PLD1 inhibition (by CAY-93), but also RSK2 inhibition (by BI-D1870), completely prevented the recruitment of Spo20p to the cell periphery, highlighting the importance of RSK2 in NGF-induced PLD1 activation and PA synthesis at the plasma membrane (Fig. $7 A, B)$. Interestingly, Spo20p expression in PC12 cells strongly reduced the number and length of the NGF-induced neurites

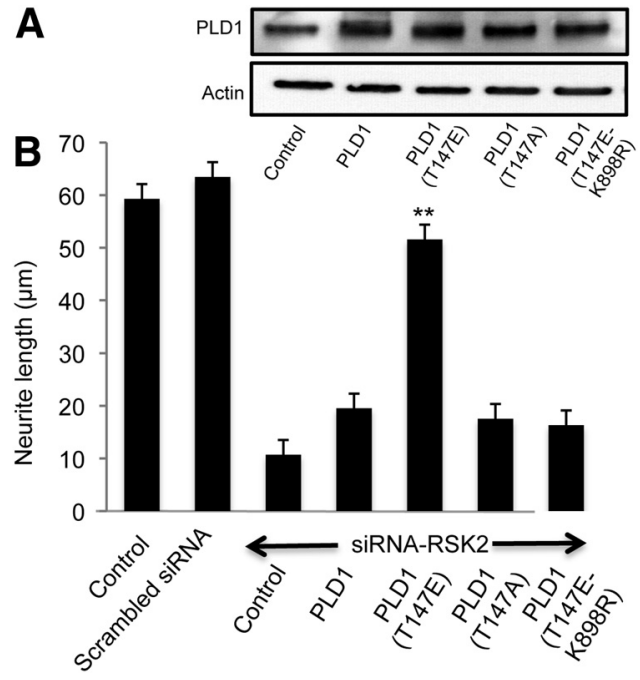

Figure 6. Phosphorylation of PLD1 is important for neurite outgrowth. $A$, Expression level of PLD1 and the various PLD1 mutants in RSK2-silenced cells. Actin staining serves as a loading control. $\boldsymbol{B}$, Neurite length after NGF treatment in PC12 cells silenced for RSK2 expression and coexpressing either WT PLD1, the phosphorylation deficient mutant PLD1(T147A), the phosphomimetic PLD1(T147E) mutant, or the phosphomimetic and kinase dead PLD1(T147EK898R) mutant. Expression of the phosphomimetic PLD1(T147E) rescued NGF-induced neurite outgrowth in cells with reduced RSK2 levels. Results were pooled from three independent experiments. 
A
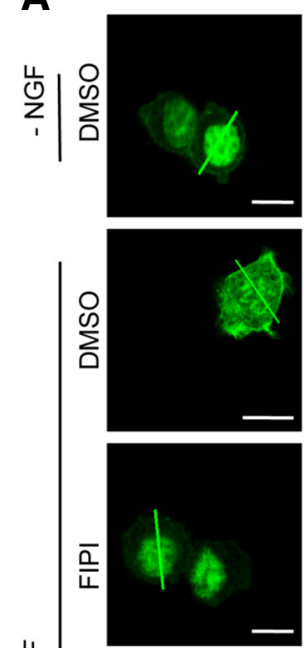

峁

启
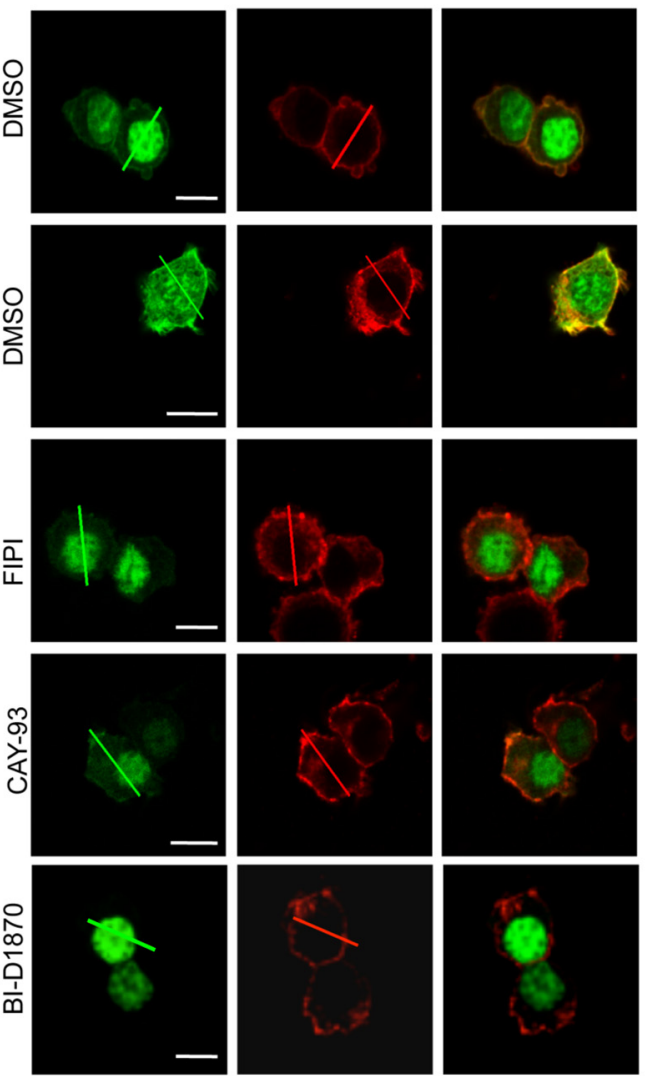

B

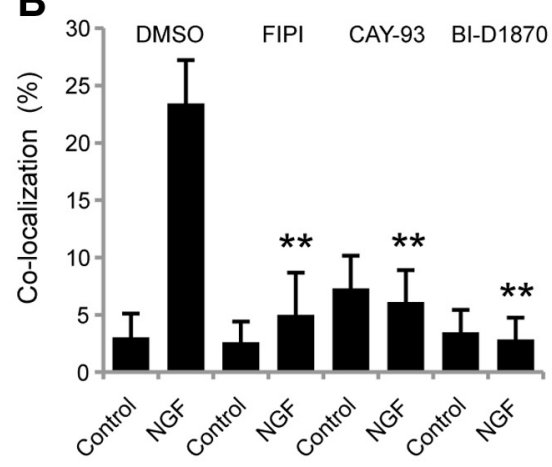

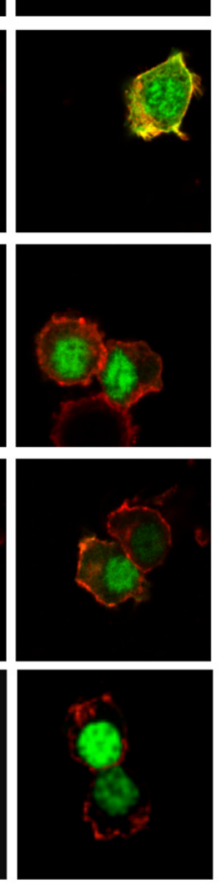

C
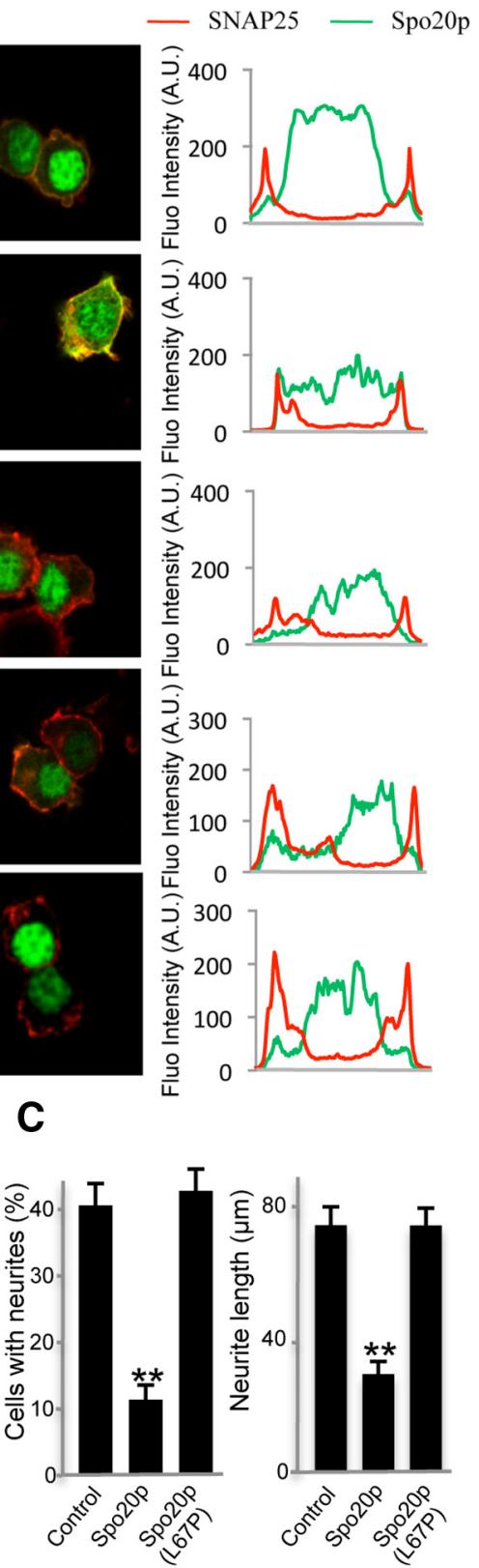

Figure 7. NGF-induced PA synthesis at the cell periphery is prevented by RSK2 and PLD1 inhibitors. A, Distribution of the PA sensor Spo20p-GFP in resting and NGF-stimulated PC12 cells. Thirty minute exposure to NGF triggers the recruitment of Spo20pGFP to the cell periphery, revealing PA synthesis at the plasma membrane. The fluorescence distribution of Spo20p-GFP and the plasma membrane marker SNAP25 along the line drawn on the pictures is represented in arbitrary units. Pre-exposure to PLD1 or RSK2 inhibitors prevented the recruitment of Spo20p to the cell periphery in NGF-stimulated cells. Scale bars, $10 \mu \mathrm{m}$. B, Quantification of the Sp020p-GFP/SNAP25 colocalization. C, Control, Spo20p, or Sp020p(L67P)-expressing cells were grown in presence of NGF and the number and length of neurites were estimated. Similar observations were obtained with $\geq 3$ different cell cultures ( $n>25$ cells in each condition).

(Fig. 7C), most likely by quenching PA and preventing its function in neurite outgrowth. In agreement with this model, expression of the mutant Spo20p(L67P), which is unable to bind to PA (Zeniou-Meyer et al., 2007), failed to affect neurite outgrowth (Fig. 7C). The molecular mechanism by which PA may control neurite outgrowth has yet to be elucidated. However, it might be related to the proposed role of PA in vesicular trafficking, i.e., a promoter of vesicle fusion with target membranes through biophysical changes in membrane topology and/or recruitment and activation of fusion promoters at the fusion site (Bader and Vitale, 2009).

Neurite initiation entails significant surface area expansion. It involves distinct pathways that require coordination between the actin cytoskeleton and fusion of vesicle to provide membrane to the growing endings (D'Allessandro et al., 2010; Gupton and Gertler, 2010). In NGF-treated PC12 cells, we observed anterograde and retrograde movement of PLD1-positives vesicles in neurites and occasionally the directional movement of PLD1-positive vesicles toward the tips of the growing neurites (Fig. $8 A)$. To further characterize these PLD1positive vesicles in PC12 cells, we tested for the presence of the vesicular SNARE proteins VAMP-2, VAMP-4, or tetanus neurotoxin insensitive VAMP/VAMP-7 (TiVAMP/VAMP-7). As shown in Figure $8 B$, PLD1 did not colocalize with VAMP-2, colocalized only partially with VAMP-4 in the perinuclear region, but strongly colocalized with VAMP-7. Interestingly after NGF treatment, VAMP-7 and PLD1 were found at the tip of growing neurites (Fig. 8C). VAMP-7 vesicles are known to play a major role in neurite outgrowth (Martinez-Arca et al., 2000). To probe the idea that RSK2activated PLD1 may play a critical role in the fusion of VAMP-7 vesicles at the tip of growing neurites, we recorded the fusion of pHluorin-VAMP-7 vesicles by TIRF microscopy (Burgo et al., 2012). When the $\mathrm{pH}$ sensitive GFP variant pHluorin is fused to the luminal domain of VAMP-7, its fluorescence is significantly quenched due to exposure to the acidic $\mathrm{pH}$ of the vesicle lumen. Upon exocytosis, luminal proteins are exposed to the extracellular medium and become fluorescent. In PC12 cells, NGF treatment triggered successive fusion events of VAMP-7 vesicles at the neurite growth cones (Fig. 9A). Treatment with the PLD1 and RSK inhibitors significantly reduced the frequency of these fusion events as revealed by the increase in the intervals between successive events (Fig. 9B,C). This observation supports the idea that RSK2-stimulated PLD1 activity is functionally involved in VAMP-7 vesicle incorporation at the growing endings of developing neurites. Finally, we silenced VAMP-7 in PC12 cells and examined the effect of the phosphomimetic mutant PLD1-T147E expression on neurite outgrowth. Neurite length in PLD1-T147E-expressing cells was $82.69 \pm 4.88 \mu \mathrm{m}$ compared with $37.67 \pm 3.47 \mu \mathrm{m}(p<0.001)$ in cells expressing both siVAMP-7 and PLD1-T147E. In other words, reducing the expression of VAMP-7 severely impaired the ability of the phosphomimetic PLD1 mutant to promote neurite outgrowth, in line with the idea that VAMP-7 is an effector for RSK2/PLD1 in the process of neurite growth.

\section{Discussion}

Despite intensive research on CLS, the relationship between genotype and phenotype remains poorly understood. Specific physiolog- 
ical roles of RSK2 are also unclear and little is currently known about the cellular effects of RSK2 in neurons. Behavioral studies in Rsk2-KO mice revealing normal motor coordination, but a profound retardation in spatial learning and a deficit in long-term spatial memory, provide evidence that RSK2 has similar roles in mental functioning in both mice and humans (Poirier et al., 2007). Although Rsk2-KO mice show no obvious brain abnormalities at the anatomical and histological levels, we show here that cortical neurons cultured from these mice display significant developmental delay. At 3 d of culture, only $20 \%$ of the Rsk2-KO mice neurons developed an axon compared with 60\% in WT neurons. These observations are in line with the recent finding that Rsk2 knockdown perturbs the differentiation of neural precursors into neurons (Dugani et al., 2010). Since we previously identified PLD1 as a target of RSK2 in neuroendocrine-regulated exocytosis (Zeniou-Meyer et al., 2008, 2009), we decided to investigate the possibility that PLD1 could be involved in RSK2-mediated neurite outgrowth. In agreement with this idea, we found that cortical neurons cultured from Pld1-KO mice displayed a significant delay in development comparable to neurons from Rsk2-KO mice. Using the classical NGF-induced neurite outgrowth assay in PC12 cells, we show that RSK2 colocalizes, phosphorylates, and regulates PLD1 activity in response to NGF stimulation. NGF-induced neurite outgrowth is severely impaired in RSK2-depleted cells, but this can be rescued by expressing a phosphomimetic mutant of PLD1. Finally, both RSK2 and PLD1 inhibitors inhibit PA synthesis and VAMP-7 vesicle fusion at growth cones in response to NGF. Together, our findings reveal a mechanism in which RSK2-mediated PLD1 activation and subsequent PA synthesis favor vesicular fusion and membrane supply required for neurite outgrowth. Previous experiments in PC12 cells suggested that RSKs might be involved in neurite outgrowth since overexpression of a catalytically active mutant of rat RSK1 was able to promote neurite growth in the absence of NGF (Silverman et al., 2004). This effect was, however, not reproduced by the overexpression of a catalytically active mutant of mouse RSK2, suggesting that only RSK2 may be intimately linked to the NGF-induced differentiation process in PC12 cells. Nevertheless, the fact that we found only a partial block of neurite outgrowth in Rsk2-KO neurons, suggests that endogenous RSK1 may be able to partially compensate the loss of RSK2 in neurons.
A

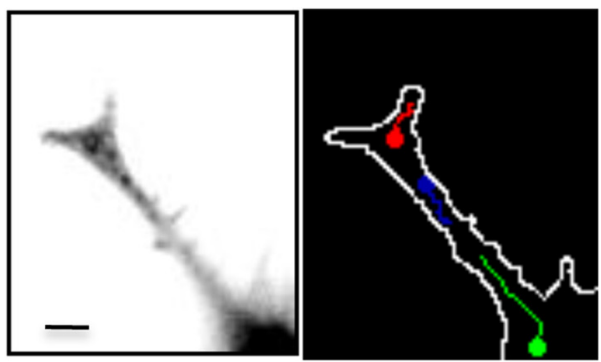

B
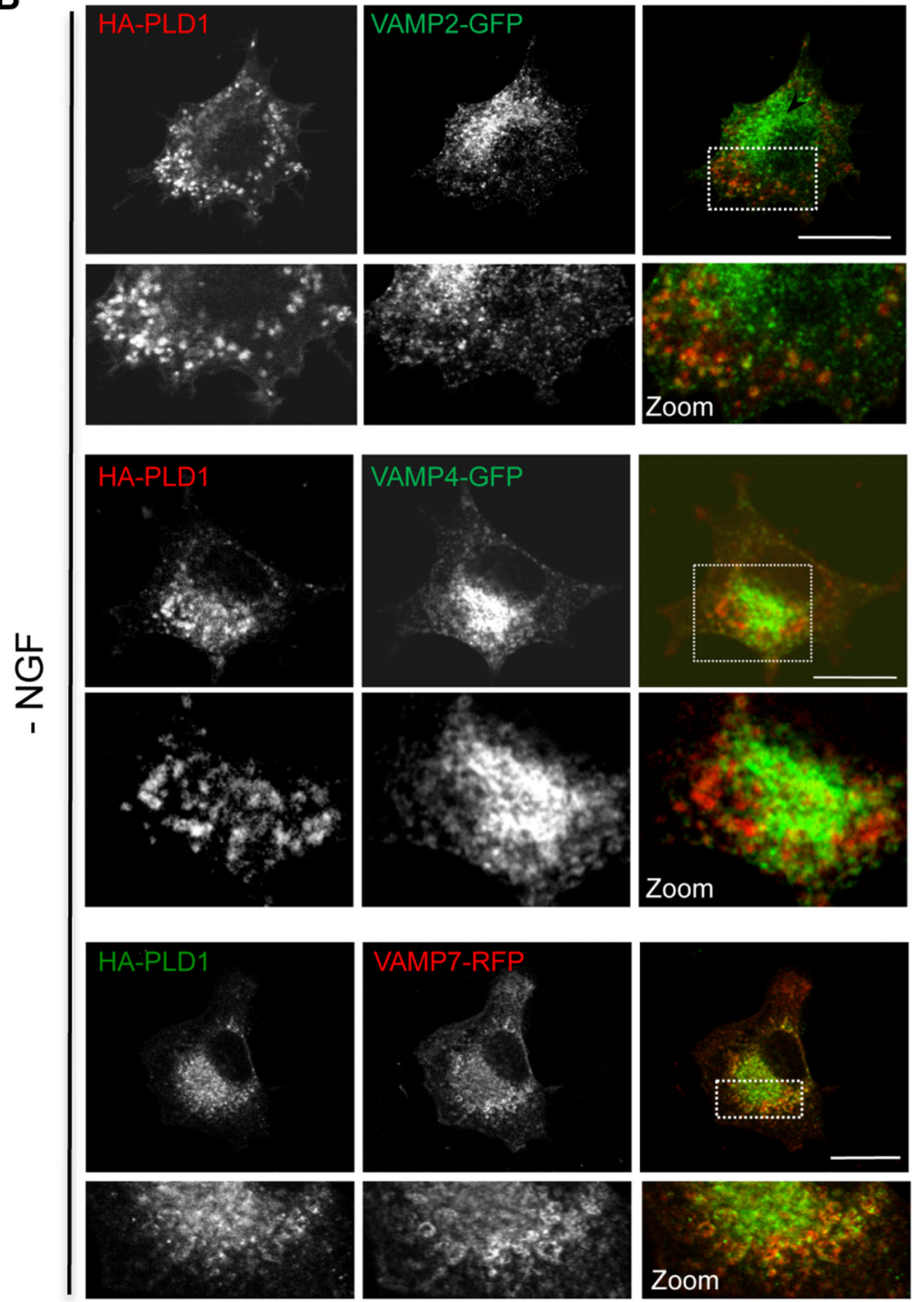

C
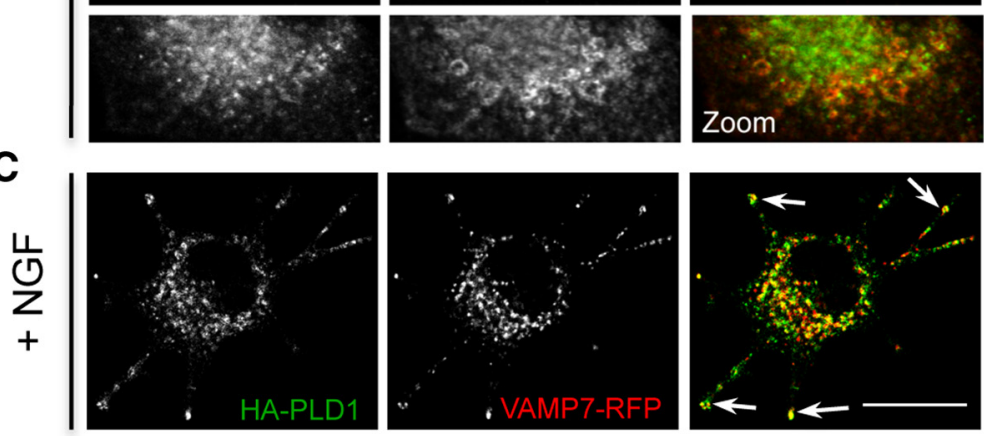

Figure 8. PLD1 is associated with VAMP-7-positive vesicles. $A, P C 12$ cells expressing PLD1-GFP were treated with NGF for $24 \mathrm{~h}$ and imaged by time-lapse video microscopy. A typical image extracted from a movie shows the vesicular pattern of PLD1-GFP, especially at the tip of the neurite (scale bar, $1 \mu \mathrm{m}$ ). PLD1-positive vesicles moved in both directions within the neurite (green and blue tracks) and toward the plasma membrane in the growth cone (red track). $B$, Colocalization of PLD1 and GFP-VAMP-2, GFP-VAMP-4, or RFP-VAMP-7 in PC12 cells. Selected areas were zoomed. C, NGF treatment induced a partial colocalization of PLD1 and VAMP-7 atneurite tips (arrows). Scale bars, $10 \mu \mathrm{m}$. Similar observations were obtained with $\geq 3$ different cell cultures. 
A
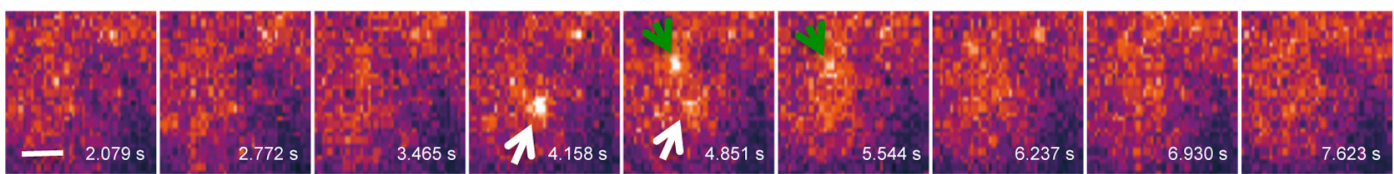

B
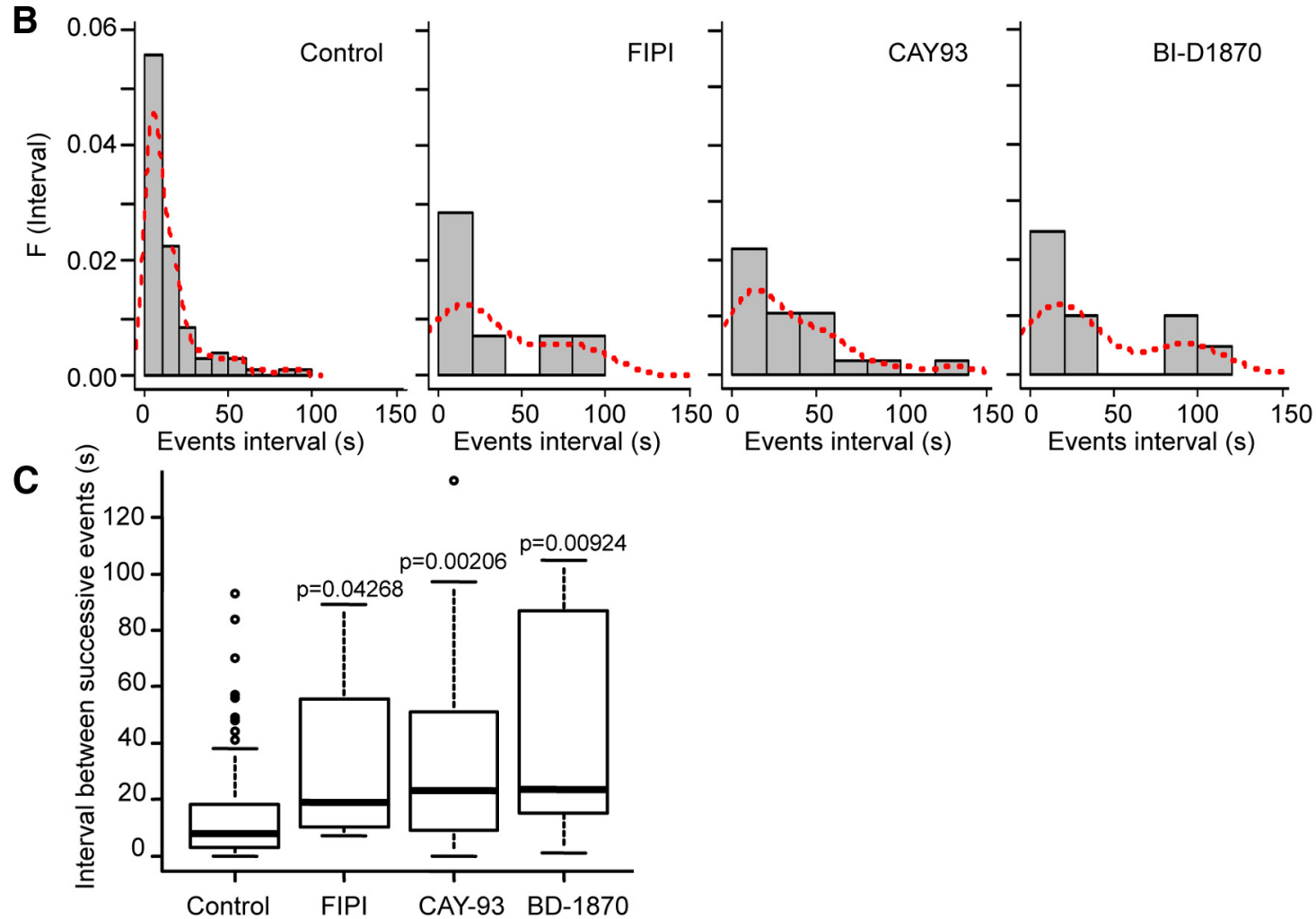

Events interval (s) Events interval (s)

Figure 9. RSK2 and PLD1 regulate VAMP-7 vesicle fusion rate at the ends of growing neurites. A, Portion of a PC12 neurite tip expressing VAMP-7-pHluorine imaged by TIRF microscopy for 3 min Twelve consecutive images from a $1.44 \mathrm{~Hz}$ movie are shown. Time is marked on each image. Arrows show the appearance and disappearance of two VAMP-7-pHluorine signals reflecting vesicle fusion and a shift of pHluorine signal due to the neutralization of the intravesicular pH. Scale bar, $1 \mu \mathrm{m}$. B, C, PC12 cells expressing VAMP-7-pHluorin were incubated overnight with NGF. Before VAMP-7 vesicle recording by TIRF microscopy, cells were preincubated with PLD inhibitors (FIPI or CAY-93) or RSK inhibitor (BI-D1870) for 30 min. The intervals between successive events (in seconds) were determined with ImageJ and their frequency plotted. The red dotted lines indicate the distribution of intervals between VAMP-7-pHluorine vesicles fusion events. Significance was determined by Wilcoxon signed-rank test.

PLD activity has been implicated in neurite outgrowth in various neuronal models for over a decade, but most of these findings rely on the use of ethanol as a nonspecific inhibitor of PA synthesis and in most cases the PLD isoform involved was not identified. Using for the first time a combination of $\mathrm{KO}$ mice model, a gene silencing approach, and the recently described isoform-specific PLD inhibitors, we demonstrate here that PLD1 contributes to neurite outgrowth but also to dendrite branching and spine development. Yet, in apparent contradiction, PLD1 has recently been described to negatively regulate dendritic branching in hippocampal neurons (Zhu et al., 2012). These findings were obtained from a different type of neuron, which may explain the discrepancy. But the discrepancy might instead stem from the method used to modify PLD1 expression levels, i.e., overexpression or silencing at $3 \mathrm{DIV}$. In the present study, PLD1 was genetically knocked down, implying that critical functions of PLD1 in early stages of neurite outgrowth could not be missed. It is also worth mentioning that our results are in line with the previous report showing that the GTPase RalB promotes branching through a pathway involving PLD (Lalli and Hall, 2005).

We have previously reported that RSK2 phosphorylation of PLD1 is important for regulated exocytosis in chromaffin cells (Zeniou-Meyer et al., 2008) and for neurotransmission (Humeau et al., 2001), indicating that this pathway may regulate various vesicular trafficking events in neurosecretory cells. In support of this hypothesis, PLD1 was shown to regulate intracellular trafficking of presenilin-1, a critical component of the $\gamma$-secretase complex (Liu et al., 2009). Of particular interest, upregulation of PLD1 rescues impaired $\beta$ APP trafficking to the plasma membrane and defects in neurite outgrowth capacity in a familial form of Alzheimer disease presenilin-1 mutant neurons (Cai et al., 2006). It is thus tempting to speculate that the RSK2-phosphorylated form of PLD1 plays a key role in promoting vesicular delivery of key components for neuronal development and function.

We found that PLD1 KO also reduced the number of mature spines on dendrites. Many higher cognitive disorders, such as mental retardation, Rett syndrome, and autism, are associated with aberrant spine morphology and an altered long-term potentiation in neuron in culture (Pavlowsky et al., 2012). Since dendritic spines are thought to represent a morphological correlate of neuronal plasticity, altered spine morphology may underlie or contribute to cognitive deficits seen in CLS. In agreement with this idea, we recently reported an alteration of long-term potentiation at cortical neuron synapses in the lateral amygdala (Zeniou-Meyer et al., 2010). Signaling cascades that are important for cytoskeletal regulation may have an impact on spine morphology. Among those, the Rho GTPase signaling pathway, 
which is known to be involved in the regulation of the actin cytoskeleton, seems to play fundamental roles in the structural plasticity of dendritic spines (Svitkina et al., 2010). The interplay between PLD1 and Rho GTPases has been shown in several cellular processes, but it remains to be established whether the altered dendrite and spine morphology observed in Pld1-KO mice, relies on an alteration of Rho activity. It is also worthwhile mentioning that the GTPase ARF6, an activator of PLD1 (Bader et al., 2004), has been reported to play a positive role in spine formation (Choi et al., 2006), in line with the findings reported here.

PLD1 synthesizes PA, a bioactive lipid that has been proposed for a role in various trafficking events, including endocytosis and regulated exocytosis in various cell types (Bader and Vitale, 2009). In the process of neurite outgrowth, PA could stimulate the fusion of vesicles with the plasma membrane for the purpose of supplying membrane components to extending neurites, but also directly or indirectly regulate actin cytoskeletal organization, which is essential for the formation of filopodia and lamellipodia at growth cones. We did not find a significant modification of actin and tubulin staining in neurons cultured from Rsk2-KO and Pld1-KO mice (data not shown). However, we observed that RSK2 and PLD1 inhibitors significantly reduced the frequency of VAMP-7 vesicle fusion in growth cones, favoring the idea that RSK2-stimulated PLD1-induced PA production plays a role in VAMP-7 vesicle incorporation at the growing endings of developing neurites. The mechanism(s) by which PA promotes membrane fusion remains debated but it may be linked to its ability to generate membrane curvature (Zeniou-Meyer et al., 2007), regulate phosphoinositol 4-5 bisphophate levels (Honda et al., 1999), and/or modulate syntaxin-1 activity (Lam et al., 2008). Our observation that expression of a PA sensor partially inhibits neurite outgrowth suggests that PA acts in part by recruiting key proteins at the vesicle fusion site.

Finally, it should be mentioned that the development in culture of neurons from Rsk2-KO and Pld1-KO models is delayed but not completely blocked. A possible explanation is that neurons compensate defects in the RSK2/PLD1 pathway by using alternative sources of PA. For instance, the PLD2 isoform has been also suggested to contribute to neurite outgrowth (Kanaho et al., 2009). Alternatively in ribbon synapses, the PA involved in synaptic vesicle trafficking arises from lysophosphatidic acid acyltransferase activity (Schwarz et al., 2011) and the diacylglycerol (DAG)-kinases can also convert DAG into PA. Nevertheless, the present results support the idea that defects in PLD1 activity and fusogenic lipid synthesis could provide an explanation at the molecular level for abnormal growth and development of neural circuits leading to the learning and memory deficits observed after RSK2 loss-of-function mutations in animal models and CLS patients.

\section{References}

Bader MF, Vitale N (2009) Phospholipase D in calcium-regulated exocytosis: lessons from chromaffin cells. Biochim Biophys Acta 1791:936-941. CrossRef Medline

Bader MF, Doussau F, Chasserot-Golaz S, Vitale N, Gasman S (2004) Coupling actin and membrane dynamics during calcium-regulated exocytosis: a role for Rho and ARF GTPases. Biochim Biophys Acta 1742:37-49. CrossRef Medline

Béglé A, Tryoen-Tóth P, de Barry J, Bader MF, Vitale N (2009) ARF6 regulates the synthesis of fusogenic lipids for calcium-regulated exocytosis in neuroendocrine cells. J Biol Chem 284:4836-4845. CrossRef Medline

Burgo A, Proux-Gillardeaux V, Sotirakis E, Bun P, Casano A, Verraes A, Liem RK, Formstecher E, Coppey-Moisan M, Galli T (2012) A molecular network for the transport of the TI-VAMP/VAMP7 vesicles from cell center to periph. Dev Cell 23:166-180. CrossRef Medline
Cai D, Zhong M, Wang R, Netzer WJ, Shields D, Zheng H, Sisodia SS, Foster DA, Gorelick FS, Xu H, Greengard P (2006) Phospholipase D1 corrects impaired betaAPP trafficking and neurite outgrowth in familial Alzheimer's disease-linked presenilin-1 mutant neurons. Proc Natl Acad Sci U S A 103:1936-1940. CrossRef Medline

Choi S, Ko J, Lee JR, Lee HW, Kim K, Chung HS, Kim H, Kim E (2006) ARF6 and EFA6A regulate the development and maintenance of dendritic spines. J Neurosci 26:4811-4819. CrossRef Medline

Corrotte M, Chasserot-Golaz S, Huang P, Du G, Ktistakis NT, Frohman MA, Vitale N, Bader MF, Grant NJ (2006) Dynamics and function of phospholipase D and phosphatidic acid during phagocytosis. Traffic 7:365377. CrossRef Medline

Craig AM, Banker G (1994) Neuronal polarity. Annu Rev Neurosci 17:267310. CrossRef Medline

D’Allessandro R, Racchetti G, Meldolesi J (2010) Outgrowth of neurites is a dual process. Commun Integr Biol 3:576-578. CrossRef Medline

de Barry J, Janoshazi A, Dupont JL, Procksch O, Chasserot-Golaz S, Jeromin A, Vitale N (2006) Functional implication of neuronal calcium sensor-1 and phosphoinositol 4-kinase-beta interaction in regulated exocytosis of PC12 cells. J Biol Chem 281:18098-18111. CrossRef Medline

Du G, Altshuller YM, Vitale N, Huang P, Chasserot-Golaz S, Morris AJ, Bader MF, Frohman MA (2003) Regulation of phospholipase D1 subcellular cycling through coordination of multiple membrane association motifs. J Cell Biol 162:305-315. CrossRef Medline

Dugani CB, Paquin A, Kaplan DR, Miller FD. (2010) Coffin-Lowry syndrome: a role for RSK2 in mammalian neurogenesis. Dev Biol 347:348 359. CrossRef Medline

Elvers M, Stegner D, Hagedorn I, Kleinschnitz C, Braun A, Kuijpers ME, Boes M, Chen Q, Heemskerk JW, Stoll G, Frohman MA, Nieswandt B (2010) Impaired alpha(IIb)beta(3) integrin activation and shear-dependent thrombus formation in mice lacking phospholipase D1. Sci Signal 3:ra1. CrossRef Medline

Frödin M, Gammeltoft S (1999) Role and regulation of $90 \mathrm{kDa}$ ribosomal S6 kinase (RSK) in signal transduction. Mol Cell Endocrinol 151:65-77. CrossRef Medline

Gupton SL, Gertler FB (2010) Integrin signaling switches the cytoskeletal and exocytic machinery that drives neuritogenesis. Dev Cell 18:725-736. CrossRef Medline

Hanauer A, Young ID (2002) Coffin-Lowry syndrome: clinical and molecular features. J Med Genet 39:705-713. CrossRef Medline

Honda A, Nogami M, Yokozeki T, Yamazaki M, Nakamura H, Watanabe H, Kawamoto K, Nakayama K, Morris AJ, Frohman MA, Kanaho Y (1999) Phosphatidylinositol 4-phosphate 5-kinase alpha is a downstream effector of the small G protein ARF6 in membrane ruffle formation. Cell 99:521-532. CrossRef Medline

Humeau Y, Vitale N, Chasserot-Golaz S, Dupont JL, Du G, Frohman MA, Bader MF, Poulain B (2001) A role for phospholipase D1 in neurotransmitter release. Proc Natl Acad Sci U S A 98:15300-15305. CrossRef Medline

Hunter AG (2002) Coffin-Lowry syndrome: a 20-year follow-up and review of long-term outcomes. Am J Med Genet 111:345-355. CrossRef Medline

Jan YN, Jan LY (2010) Branching out: mechanisms of dendritic arborization. Nat Rev Neurosci 11:316-328. CrossRef Medline

Jaworski J, Spangler S, Seeburg DP, Hoogenraad CC, Sheng M (2005) Control of dendritic arborization by the phosphoinositide-3'-kinase-Aktmammalian target of rapamycin pathway. J Neurosci 25:11300-11312. CrossRef Medline

Kanaho Y, Funakoshi Y, Hasegawa H (2009) Phospholipase D signalling and its involvement in neurite outgrowth. Biochim Biophys Acta 1791: 898-904. CrossRef Medline

Kassas N, Tryoen-Tóth P, Corrotte M, Thahouly T, Bader MF, Grant NJ, Vitale N (2012) Genetically encoded probes for phosphatidic acid. Methods Cell Biol 108:445-459. CrossRef Medline

Kesler SR, Simensen RJ, Voeller K, Abidi F, Stevenson RE, Schwartz CE, Reiss AL (2007) Altered neurodevelopment associated with mutations of RSK2: a morphometric MRI study of Coffin-Lowry syndrome. Neurogenetics 8:143-147. CrossRef Medline

Lalli G, Hall A (2005) Ral GTPases regulate neurite branching through GAP-43 and the exocyst complex. J Cell Biol 171:857-869. CrossRef Medline

Lam AD, Tryoen-Toth P, Tsai B, Vitale N, Stuenkel EL (2008) SNARE- 
catalyzed fusion events are regulated by syntaxin1A-lipid interactions. Mol Biol Cell 19:485-497. Medline

Lewis JA, Scott SA, Lavieri R, Buck JR, Selvy PE, Stoops SL, Armstrong MD, Brown HA, Lindsley CW (2009) Design and synthesis of isoformselective phospholipase D (PLD) inhibitors. Part I: impact of alternative halogenated privileged structures for PLD1 specificity. Bioorg Med Chem Lett 19:1916-1920. CrossRef Medline

Liu Y, Zhang YW, Wang X, Zhang H, You X, Liao FF, Xu H (2009) Intracellular trafficking of presenilin 1 is regulated by beta-amyloid precursor protein and phospholipase D1. J Biol Chem 284:12145-12152. CrossRef Medline

Lopez CI, Pelletán LE, Suhaiman L, De Blas GA, Vitale N, Mayorga LS, Belmonte SA (2012) Diacylglycerol stimulates acrosomal exocytosis by feeding into a PKC- and PLD1-dependent positive loop that continuously supplies phosphatidylinositol 4,5-bisphosphate. Biochim Biophys Acta 1821:1186-1199. CrossRef Medline

Manouvrier-Hanu S, Amiel J, Jacquot S, Merienne K, Moerman A, Coëslier A, Labarriere F, Vallée L, Croquette MF, Hanauer A (1999) Unreported RSK2 missense mutation in two male sibs with an unusually mild form of Coffin-Lowry syndrome. J Med Genet 36:775-778. CrossRef Medline

Martinez-Arca S, Alberts P, Zahraoui A, Louvard D, Galli T (2000) Role of tetanus neurotoxin insensitive vesicle-associated membrane protein (TIVAMP) in vesicular transport mediating neurite outgrowth. J Cell Biol 149:889-900. CrossRef Medline

Pavlowsky A, Chelly J, Billuart P (2012) Emerging major synaptic signaling pathways involved in intellectual disability. Mol Psychiatry 17:682-693. CrossRef Medline

Pereira PM, Schneider A, Pannetier S, Heron D, Hanauer A (2010) Coffin Lowry syndrome. Eur J Hum Genet 18:627-633. CrossRef Medline

Poirier R, Jacquot S, Vaillend C, Soutthiphong AA, Libbey M, Davis S, Laroche S, Hanauer A, Welzl H, Lipp HP, Wolfer DP (2007) Deletion of the Coffin-Lowry syndrome gene Rsk2 in mice is associated with impaired spatial learning and reduced control of exploratory behavior. Behav Genet 37:31-50. CrossRef Medline

Sapkota GP, Cummings L, Newell FS, Armstrong C, Bain J, Frodin M, Grauert M, Hoffmann M, Schnapp G, Steegmaier M, Cohen P, Alessi DR (2007) BI-D1870 is a specific inhibitor of the p90 RSK (ribosomal S6 kinase) isoforms in vitro and in vivo. Biochem J 401:29-38. CrossRef Medline

Schwarz K, Natarajan S, Kassas N, Vitale N, Schmitz F (2011) The synaptic ribbon is a site of phosphatidic acid generation in ribbon synapses. J Neurosci 31:15996-16011. CrossRef Medline

Silverman E, Frödin M, Gammeltoft S, Maller JL (2004) Activation of p90 Rsk1 is sufficient for differentiation of PC12 cells. Mol Cell Biol 24:1057310583. CrossRef Medline

Stephenson JB, Hoffman MC, Russell AJ, Falconer J, Beach RC, Tolmie JL, McWilliam RC, Zuberi SM (2005) The movement disorders of CoffinLowry syndrome. Brain Dev 27:108-113. CrossRef Medline

Su W, Yeku O, Olepu S, Genna A, Park JS, Ren H, Du G, Gelb MH, Morris AJ, Frohman MA (2009) 5-Fluoro-2-indolyl des-chlorohalopemide (FIPI), a phospholipase D pharmacological inhibitor that alters cell spreading and inhibits chemotaxis. Mol Pharmacol 75:437-446. CrossRef Medline

Svitkina T, Lin WH, Webb DJ, Yasuda R, Wayman GA, Van Aelst L, Soderling SH (2010) Regulation of the postsynaptic cytoskeleton: roles in development, plasticity, and disorders. J Neurosci 30:14937-14942. CrossRef Medline

Trivier E, De Cesare D, Jacquot S, Pannetier S, Zackai E, Young I, Mandel JL, Sassone-Corsi P, Hanauer A (1996) Mutations in the kinase Rsk-2 associated with Coffin-Lowry syndrome. Nature 384:567-570. CrossRef Medline

Vitale N, Horiba K, Ferrans VJ, Moss J, Vaughan M (1998) Localization of ADP-ribosylation factor domain protein 1 (ARD1) in lysosomes and Golgi apparatus. Proc Natl Acad Sci U S A 95:8613-8618. CrossRef Medline

Vitale N, Caumont AS, Chasserot-Golaz S, Du G, Wu S, Sciorra VA, Morris AJ, Frohman MA, Bader MF (2001) Phospholipase D1: a key factor for the exocytotic machinery in neuroendocrine cells. EMBO J 20:24242434. CrossRef Medline

Yang X, Matsuda K, Bialek P, Jacquot S, Masuoka HC, Schinke T, Li L, Brancorsini S, Sassone-Corsi P, Townes TM, Hanauer A, Karsenty G (2004) ATF4 is a substrate of RSK2 and an essential regulator of osteoblast biology; implication for Coffin-Lowry syndrome. Cell 117:387-398. CrossRef Medline

Zeniou M, Ding T, Trivier E, Hanauer A (2002) Expression analysis of RSK gene family members: the RSK2 gene, mutated in Coffin-Lowry syndrome, is prominently expressed in brain structures essential for cognitive function and learning. Hum Mol Genet 11:2929-22940. CrossRef Medline

Zeniou-Meyer M, Zabari N, Ashery U, Chasserot-Golaz S, Haeberlé AM, Demais V, Bailly Y, Gottfried I, Nakanishi H, Neiman AM, Du G, Frohman MA, Bader MF, Vitale N (2007) Phospholipase D1 production of phosphatidic acid at the plasma membrane promotes exocyto- sis of large dense-core granules at a late stage. J Biol Chem 282:21746-21757. CrossRef Medline

Zeniou-Meyer M, Liu Y, Béglé A, Olanich ME, Olanish M, Hanauer A, Becherer U, Rettig J, Bader MF, Vitale N (2008) The Coffin-Lowry syndrome-associated protein RSK2 is implicated in calcium-regulated exocytosis through the regulation of phospholipase D1. Proc Natl Acad Sci U S A 105:8434-8439. CrossRef Medline

Zeniou-Meyer M, Béglé A, Bader MF, Vitale N (2009) The Coffin-Lowry syndrome-associated protein RSK2 controls neuroendocrine secretion through the regulation of phospholipase D1 at the exocytotic site. Ann N Y Acad Sci 1152:201-208. CrossRef Medline

Zeniou-Meyer M, Gambino F, Ammar MR, Humeau Y, Vitale N (2010) The Coffin-Lowry syndrome-associated protein rsk2 and neurosecretion. Cell Mol Neurobiol 30:1401-1406. CrossRef Medline

Zhu YB, Kang K, Zhang Y, Qi C, Li G, Yin DM, Wang Y (2012) PLD1 negatively regulates dendritic branching. J Neurosci 32:7960-7969. CrossRef Medline 